\title{
Adaptation of Seaweed Farmers in Zanzibar to the Impacts of Climate Change
}

\author{
Georgia de Jong Cleyndert, Rebecca Newman, Cecile Brugere, \\ Aida Cuni-Sanchez, and Robert Marchant
}

\section{Contents}

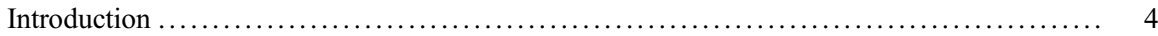

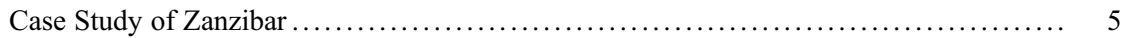

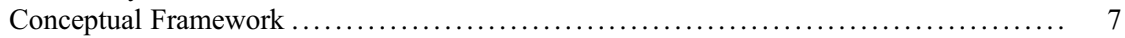

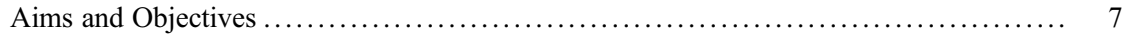

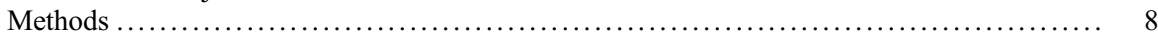

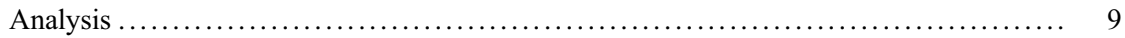

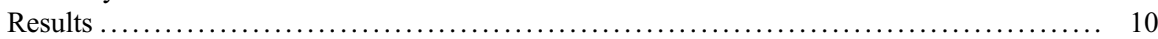

Meteorological Evidence ............................................... 11

Perceived Climatic Changes and Reported Impacts on Seaweed ................... 11

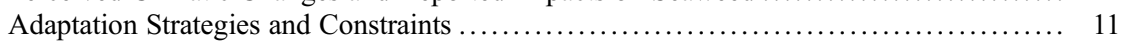

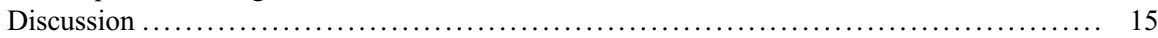

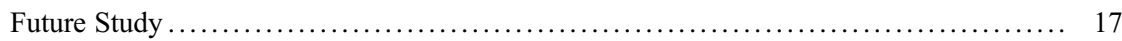

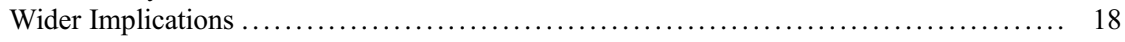

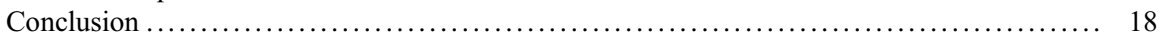

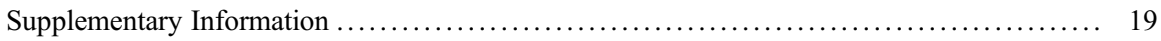

S1: List of Academics and NGOs Contacted During Scoping Phase ................. 19

S2: Participant Profiles ................................................ 19

S3: Interview Questions Used as a Guideline for the Semi-structured Interviews ........ 20

S4: Coding Strategy Used to Analyses the Seaweed Farming Interview Data ........... 22

This chapter was previously published non-open access with exclusive rights reserved by the Publisher. It has been changed retrospectively to open access under a CC BY 4.0 license and the copyright holder is "The Author(s)". For further details, please see the license information at the end of the chapter.

G. de Jong Cleyndert $(\bowtie) \cdot R$. Newman $\cdot$ A. Cuni-Sanchez $\cdot$ R. Marchant York Institute for Tropical Ecosystems, Department of Environment and Geography, University of York, York, North Yorkshire, UK

e-mail: georgiadejongcleyndert@gmail.com

C. Brugere

Soulfish Research and Consultancy, York, UK 
S5: Presen6ce Absence Data for Challenges to the Off Bottom Method .............. 23

S6: Presence Absence of Challenges for Deepwater and off Bottom Methods ........... 24

S7: Percentage of Participants Spending Their Income from Seaweed Farming on Various

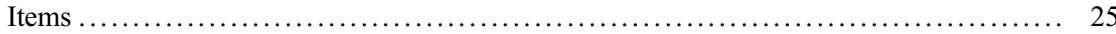

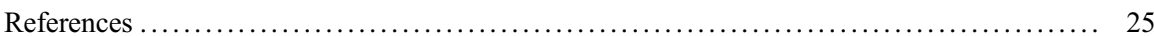

\section{Abstract}

Seaweed farming is an important alternative livelihood activity that has been heralded as a development success story. It has advanced women's empowerment and economic liberation in coastal communities in Zanzibar, despite recent declines in its production. Using data from 36 semistructured interviews, we explore the impacts of climate change on seaweed farming in Zanzibar and the coping and adaptation strategies available to farmers. Interviews reveal that climatic changes observed in Zanzibar are characterized by increased temperatures, increased winds, and irregular rainfall, and these changes have negatively affected coastal seaweed farming yields and quality. Combined with economic challenges, these environmental stressors are threatening the sustainability of seaweed farming and the wider development impacts that have been gained over the past decades. Establishing seaweed farms in deeper water, using new technologies, could be an adaptation method to overcome rising temperatures; however, there are significant socioeconomic barriers for this to happen. For example, women lack access to boats and the ability to swim. Adaptation options to the increasing impacts of climate change will be possible only with institutional support, significant investment, and through the empowerment of women and the participation local communities.

\section{Keywords}

Development $\cdot$ Climate variability $\cdot$ Coastal communities $\cdot$ Gender $\cdot$ Coping strategies

\section{Introduction}

The livelihoods of coastal communities are strongly linked to the health of the coastal and marine ecosystems on which they rely (Salafsky and Wollenberg 2000). These socioecological systems are vulnerable to sudden shocks and longterm change, including climate change, and communities often exhibit a high incidence of poverty that can be exacerbated by these shocks (Tobisson 2014; Ferrol-Schulte et al. 2015; Cohen et al. 2016). Alternative and diversification of livelihood activities are popular intervention options aimed at elevating the socioeconomic status of coastal communities and reducing the pressure on marine resources (Sievanen et al. 2005). To be successful, however, these alternative livelihood activities must be resilient to fluctuations in ecological, economic, and social systems (Allison and Ellis 2001; Newman et al. 2020). 
Seaweed farming is an alternative livelihood activity that has been promoted in many tropical developing countries (Crawford 2002; Sievanen et al. 2005) because of its low initial capital investment and short-farming cycle (Mshigeni 1973; Valderrama et al. 2015) which provides a fast return on investment (Valderrama et al. 2015). The positive socioeconomic impacts of seaweed farming have been documented in countries including the Philippines, Indonesia, Tanzania, and the Pacific Islands (Sievanen et al. 2005; Msuya 2006a; Namudu and Pickering 2006; Arnold 2008). However, these successes have also been contested (Bryceson 2002; Fröcklin et al. 2012) and seaweed farming is prone to environmental and economic boom-and-bust cycles (Valderrama et al. 2015). This raises questions about its resilience to ecological, economic, and social system fluctuations, particularly the impacts of climate change, and therefore about the sustainability of seaweed farming as an alternative livelihood activity (Allison and Ellis 2001).

\section{Case Study of Zanzibar}

Zanzibar is a semi-independent archipelago within the United Republic of Tanzania and its population rely heavily on a vulnerable marine resource base (Suckall et al. 2014). Seaweed farming was introduced in 1989 using the offbottom method to farm Kappaphycus alvarezii (commercially known as cottonii) and Eucheuma denticulatum (spinosum) in the intertidal zone (Fig. 1) (Msuya 2011). This method involves tying algal fronds to ropes attached between wooden pegs driven into the sediment (Eklöf et al. 2012). Farming cycles are 4-10 weeks, depending on growth rates (Eklöf et al. 2012). Seaweed is dried on the ground over several days and sold to a company to be exported and processed into carrageenan (Fig. 1). Seaweed farming spread rapidly throughout Zanzibar and mainland Tanzania and yearly production increased from 800 tons (dry weight) per year in 1990 to about 11,000 t in 2002 (Eklöf et al. 2012). Farming employs 15,000-20,000 people in Zanzibar, of which 90\% are women (Msuya 2006a; Fröcklin et al. 2012). In a traditionally conservative Muslim society, seaweed farming provides women with an opportunity to earn a regular cash income, negotiate household needs, and gain economic independence (Wallevik and Jiddawi 2001). It has been contended that seaweed farming has increased women's security at both the household and community level (Wallevik and Jiddawi 2001). However, despite initial successes, the industry in Zanzibar struggles to compete with global seaweed markets and there has been a production decline of 47\% between 2002 and 2012 (Eklöf et al. 2012). The combination of low-sale price and seaweed die-offs, linked to climate change and overgrowth of fouling organisms such as epiphytes (Msuya et al. 2007; Msuya 2011; Eklöf et al. 2012), have caused many farmers to reduce their farm size or abandon the activity altogether (Bryceson 2002; Eklöf et al. 2005).

Adaptation initiatives aim to increase the value of seaweed and improve the livelihoods of the women who farm it. For example, the SeaPoWer project has introduced a new technology to farm cottonii (the more valuable species) in the 


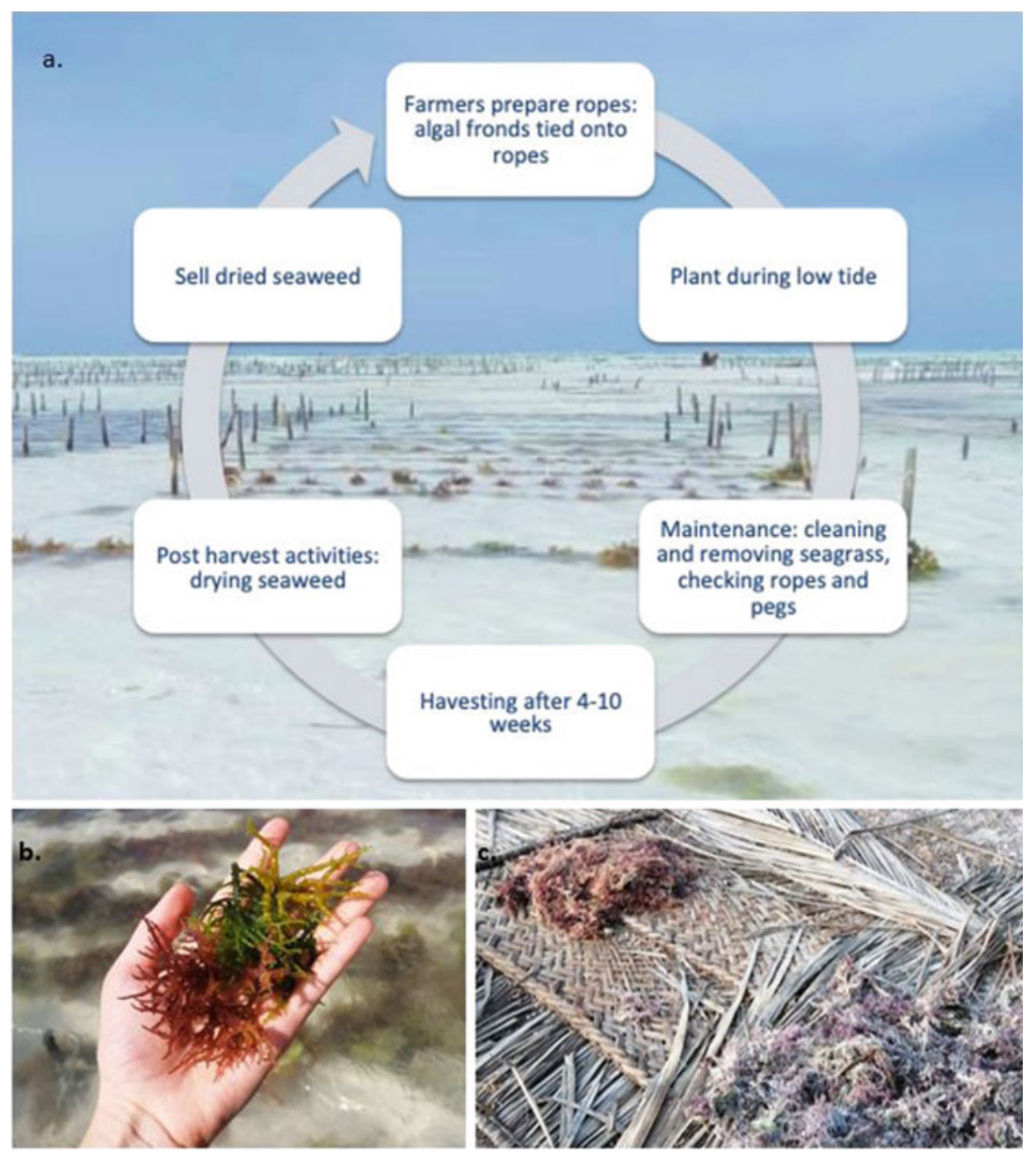

Fig. 1 (a) The seaweed farming cycle using the off-bottom method. (Adapted from Fröcklin et al. 2012). Background photo of seaweed farms in Paje, Zanzibar; (b) Fresh Eucheuma denticulatum (spinosum); (c) Two piles of seaweed drying on palm leaf matting outside Jambiani village. (All photos taken by the author)

deeper water $(>8 \mathrm{~m})$ using tubular nets and has provided a boat and other equipment to two groups of farmers (Brugere et al. 2019). Value addition training has been provided by academics and NGOs to enable women to process seaweed into more valuable products such as soap, shampoo, cookies, and juice (ZaSCI 2019). Some women have formed "clusters" to share costs of equipment and strengthen their business. Another example of an initiative is The Seaweed Co., a business providing seaweed farm tours and products to tourists, where farmers are employed full time and receive a fixed salary. Adaptation initiatives 
may increase the sustainability of seaweed farming in Zanzibar; however, their accessibility, effectiveness, and resilience remain to be assessed.

\section{Conceptual Framework}

Sustainable livelihoods, adaptation, and gender equality are key concepts to be considered in relation to the unique socioecological system of seaweed farming in Zanzibar. A livelihood is understood in relation to natural, human, economic, and social capital and is considered sustainable if it can cope with present and future shocks and stresses, while not undermining natural resources (Scoones 1998; Serrat 2017; Quandt 2018). Considering the strong interrelations between environmental conditions and seaweed farming outcomes, attention needs to be paid to the implications of environmental change. Where previous literature has emphasized the challenges that environmental change can pose (Hassan and Othman 2019; Makame and Shackleton 2019) more attention needs to be paid to if, and how, people are responding. Therefore, this study adopts principles from the dynamic environmental sustainability of livelihoods (DESL) framework, which focuses on dynamic responses to change (Newman et al. 2020). Typically, those who are unable to cope, by making temporary adjustments, or to make long-term adaptations are vulnerable and unlikely to attain sustainable livelihoods (Scoones 1998). Responses to shocks and stresses include extensification, intensification, and diversification (Suckall et al. 2014). With regard to seaweed farming, these can be understood as increasing the geographical area where seaweed is farmed, increasing the time spent on the farm, and finally, taking on additional livelihood activities. Long-term adaptations are the actions of individuals, communities and governments undertaken for the purpose of improving or protecting livelihoods (Adger et al. 2005). The capacity to adapt is shaped by socioinstitutional factors, including social identities and power relations, which include gender inequalities (Brown and Westaway 2011). The sensitivity of seaweed farming to environmental fluctuations and climate change make it particularly susceptible to shocks and stresses (Msuya and Porter 2014) and the unique nature of this femaledominated industry in the context of gender inequalities in Zanzibar, may impact farmers' ability to adapt. Assessing the viability of coping and long-term adaptation strategies is essential for understanding its future importance as an alternative livelihood activity. As such, we focus on adaptive strategies alongside barriers to adoption whilst critically reflecting on how such barriers might be overcome.

\section{Aims and Objectives}

This study aims to explore whether seaweed farmers in Zanzibar can adapt to climate change to ensure its continued sustainability as a livelihood diversification option. Firstly, we assess the environmental changes that are occurring in Zanzibar and farmers' perceptions of these changes. Secondly, we identify the challenges that women are facing, particularly in relation to climate change, and the effects these 
challenges have on production. Finally, we explore how farmers are responding to change, the adaptation strategies available and the barriers to adaptation. In doing so, findings from this work contribute to understanding the effectiveness of adaptation options and to developing recommendations for enhancing the sustainability of seaweed-related interventions.

\section{Methods}

Meetings took place with key NGOs and academics working with seaweed farming in Zanzibar to contextualize the project and gather additional background information, found in the supplementary information (S1: List of Academics and NGOs Contacted During Scoping Phase). Thirty-six semistructured interviews were carried out with seaweed farmers from five villages on Unguja, the largest island of the Zanzibar archipelago (Fig. 2, S2: Participant Profiles); participants were sought with the support of academics and NGOs working in Zanzibar. Thirty-four farmers were female, two were male and ages ranged between 23 and 70, with the average age of 45. Four different groups of farmers were selected to represent different types of seaweed farming options on the island (Table 1). Groups were identified during the scoping phase and a purposive sampling strategy was used to gain representation of the four identified groups of seaweed farmers. This number of participants was deemed an adequate sample size to permit case-orientated analysis while providing a new understanding of experience (Sandelowski 1995).

Interviews were semistructured to allow for supplementary information to be incorporated into the discussion. Interviews were carried out in participants' homes with the assistance of a translator and were recorded using a mobile phone if consent was given. The translator had an academic background in marine sciences and translated from Swahili to English. A meeting was held with the translator before interviews commenced to ensure that translation and interpretation of questions were accurate. Furthermore, to minimize misinterpretation, there was mutual consultation between the translator and the researcher throughout translation during interviews to fully unravel answers (Temple and Young 2004). Six pilot interviews were carried out and questions were adapted to make them clearer for participants and to make the challenges section less restrictive and allow participants to talk more openly and in depth about the challenges they were experiencing.

Questions were developed using themes that were based around the key aims and objectives (S3: Interview Questions Used as a Guideline for the Semi-structured Interviews). The first section gathered background information to gain understanding about whether farming contributes to financial stability in the household. The second section asked farmers to consider challenges, how these have changed over time and their coping strategies. Adaptation methods were considered by opening up conversation about deepwater farming and value addition (if applicable) and ways to make farming easier. The final question was very open-ended, allowing participants to freely add any information that they deemed important. Interviews lasted between 20 and $40 \mathrm{~min}$. Participants received a small remuneration for their time according to local customs (4000 Tsh / US\$ 1.5). 


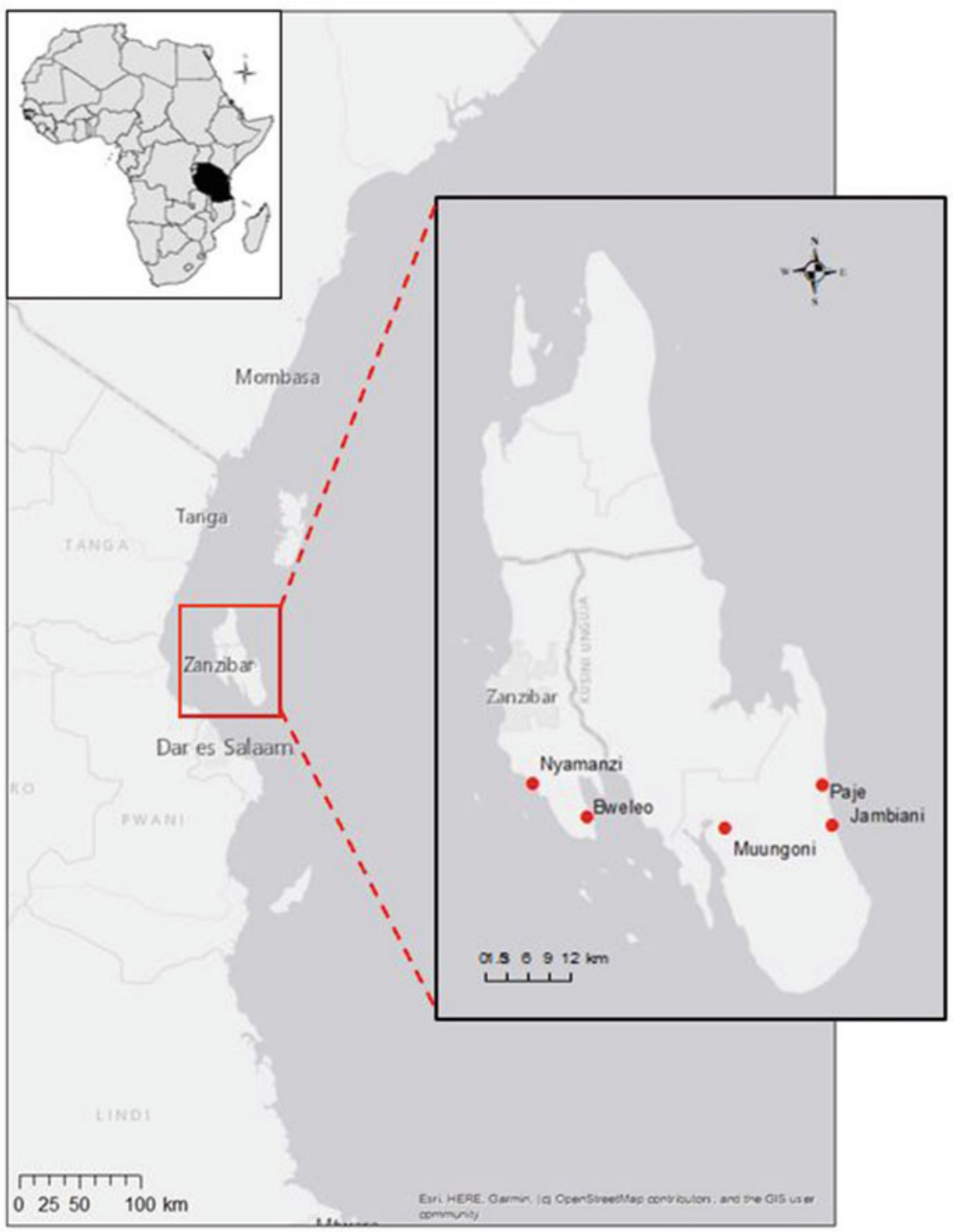

Fig. 2 Map of Zanzibar. Red dots indicate villages where participants were interviewed

\section{Analysis}

Interview notes were studied to identify key themes and concepts emerging from the data (Spencer et al. 2003). Thematic categories were based on the objectives but labeled using language from participants to ensure that analysis remained embedded in the data (Spencer et al. 2003). Interview scripts were then systematically coded 
Table 1 Summary of the groups interviewed. (No. = number of participants)

\begin{tabular}{l|l|l|l|l}
\hline Group & No. & Description & $\begin{array}{l}\text { Method of } \\
\text { farming }\end{array}$ & $\begin{array}{l}\text { Value } \\
\text { addition? }\end{array}$ \\
\hline $\begin{array}{l}\text { Independent } \\
\text { Farmers }\end{array}$ & 9 & $\begin{array}{l}\text { Farmers working alone, receiving no } \\
\text { institutional support }\end{array}$ & Off-bottom & $\boldsymbol{\chi}$ \\
\hline $\begin{array}{l}\text { Value } \\
\text { addition }\end{array}$ & 11 & $\begin{array}{l}\text { Farmers making value addition products, } \\
\text { part of a "cluster" }\end{array}$ & Off-bottom & $\checkmark$ \\
\hline Sea PoWer & 10 & $\begin{array}{l}\text { Received equipment and training to farm } \\
\text { in the deepwater using tubular nets }\end{array}$ & $\begin{array}{l}\text { Off-bottom } \\
\text { and deepwater }\end{array}$ & $\boldsymbol{\chi}$ \\
\hline Seaweed Co. & 6 & $\begin{array}{l}\text { Employed 6 days per week, receive a } \\
\text { wage. Business sells tours to tourists }\end{array}$ & Off-bottom & $\checkmark$ \\
\hline
\end{tabular}

under thematic categories using NVivo 12 (version 12.4.0) (S4: Coding Strategy Used to Analyses the Seaweed Farming Interview Data). Coded information about challenges was organized into a presence-absence data format (S5: Presence Absence Data for Challenges to the Off Bottom Method, S6: Presence Absence of Challenges for Deepwater and off Bottom Methods). Statistical analyses were carried out using R (version 3.6.0). Fisher's Exact tests were run to compare challenges across the deepwater farming $(n=10)$ and the off-bottom method $(n=36)$. Further analysis took place by examining recordings and full interview notes to capture detailed illustrative quotes. Quotes were selected to capture the breadth of challenges and emerging themes.

\section{Results}

Seaweed farming is often seen as one of the few options available for women to earn an income. With limited options for other employment, it is an important livelihood activity to alleviate poverty. Income from seaweed farming varied dramatically, ranging from 20,000 to 160,000 Tsh (US\$ 9.00-69.00) per month. Farmers noted the considerably large differences in income when the harvest was "good" or "low." Challenges to seaweed farming are numerous and farmers indicated that farming has been affected by changes in climatic factors and nonclimatic stressors over the last 20 years. Climatic variables include increased sea temperatures, increased winds, and irregular rainfall (particularly impacting on the ability to dry the harvested seaweed). Other stressors include low market price and health repercussions, such as back pain and skin irritation. The more valuable species, cottonii, cannot be farmed in many areas in Zanzibar due to poor growth and die-offs driven by diseases, such as "ice-ice" disease. As a result of challenges, there has been a huge reduction in the number of farmers. For example, the number of farmers in Bweleo has been reduced from 200 to 60 (Seaweed farmer, VA, Bweleo, July 2019). This reduction in farmers echoes a decline in production across Zanzibar (Fig. 3). 


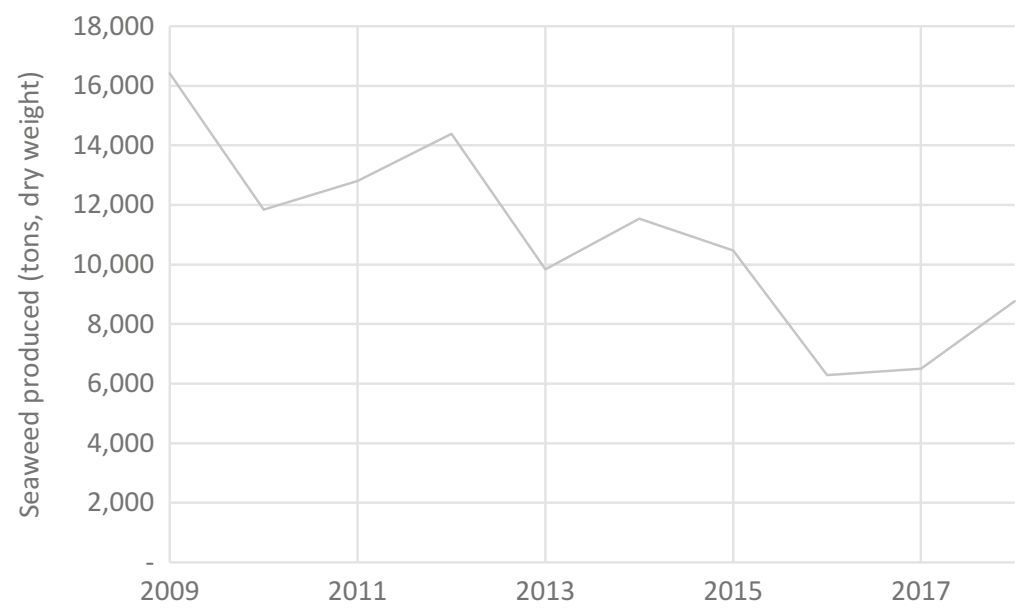

Fig. 3 Seaweed produced in Zanzibar 2009-2018. (Data acquired from Department of Fisheries Development (2019))

\section{Meteorological Evidence}

See Fig. 4.

\section{Perceived Climatic Changes and Reported Impacts on Seaweed}

Although some seaweed farmers did not observe climatic change or were unaware of why seaweed was not growing well, many were aware of changes and reported that stressors were having a big impact on seaweed farming, reducing yields. The more valuable species cottonii cannot be farmed anymore so farmers have to produce the lower value spinosum. Table 2 indicates the effects that climate stressors have on seaweed farming.

\section{Adaptation Strategies and Constraints}

Although some farmers could see no solution to the challenges they faced, there are some adaptation strategies to mitigate the effect of low market price and climatic stressors (Table 3). One coping strategy is to tend to farms more often, using "more energy" to farm. Value addition is an adaptation to the low sale price of seaweed because it can earn more money. However, it does not provide a solution to the problem of a low harvest.

Due to the disease, we try to farm seaweed, but we harvest nothing. If we want to make value addition, we have to buy from other farmers. The solution is to get a boat to farm into the deep water. (Female seaweed farmer partaking in value addition, Bweleo, July 2019) 

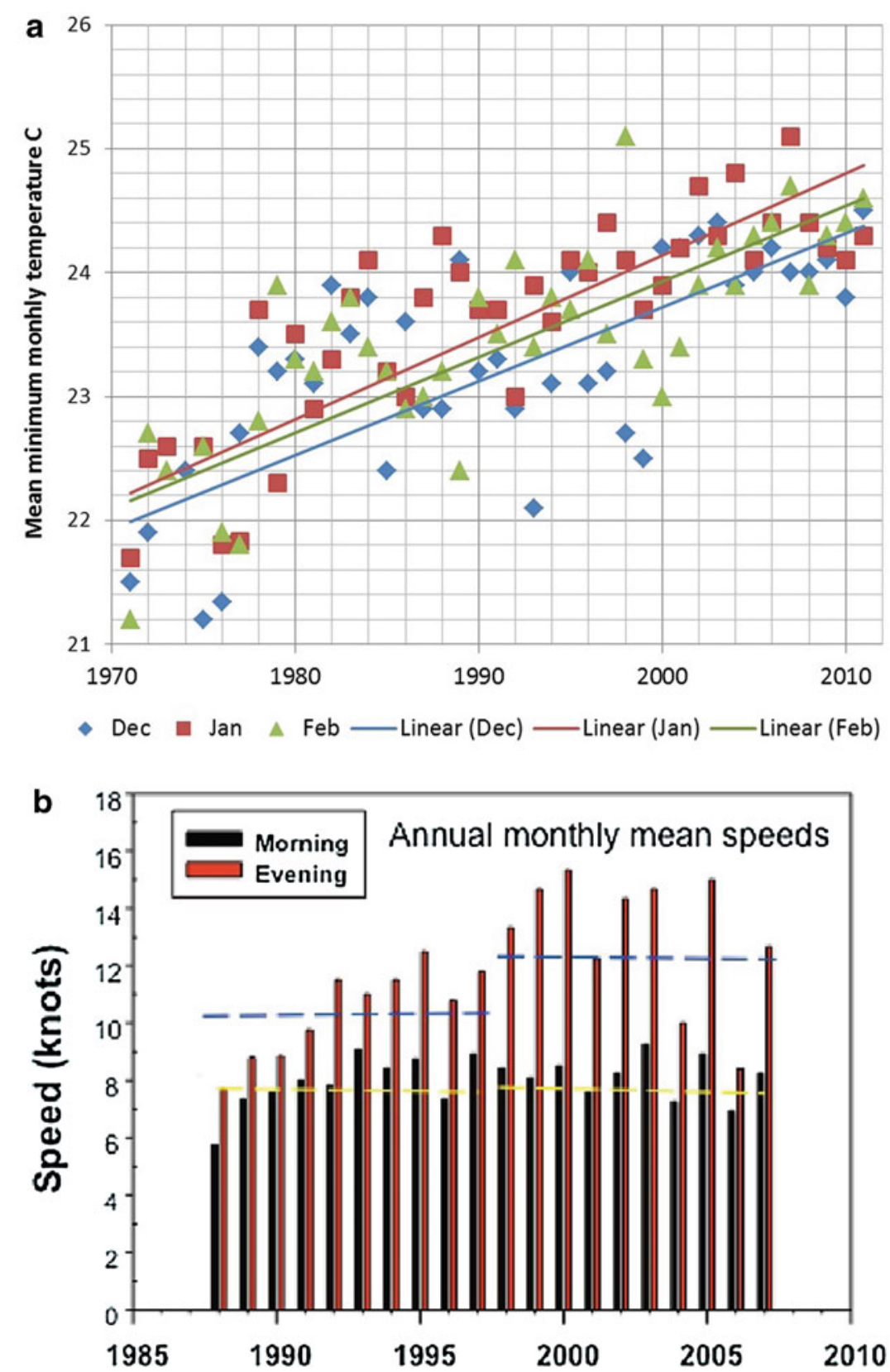

Fig. 4 (a) Mean monthly minimum temperature in January and February on Unguja show temperatures have increased strongly over the last 40 years. (Figure from Paul Watkiss, copyright permissions obtained); (b) Trends in annual monthly mean wind speeds for Unguja show that wind speeds have increased in recent decades. (Figure from Mahongo and Francis (2010), copyright permissions obtained) 
Table 2 Effects of climatic stressors on seaweed farming as mentioned by participants

\begin{tabular}{|c|c|c|c|}
\hline Stressor & Effects & $\begin{array}{l}\% \\
\text { participants }\end{array}$ & Example \\
\hline $\begin{array}{l}\text { Increased } \\
\text { sea } \\
\text { temperatures }\end{array}$ & $\begin{array}{l}\text { More disease - "ice-ice" } \\
\text { disease which turns the } \\
\text { seaweed white, causes it to } \\
\text { rot }\end{array}$ & $61 \%$ & $\begin{array}{l}\text { There is disease during the } \\
\text { summer, the water got hot and } \\
\text { boiled the seaweed (Independent } \\
\text { female farmer, Paje, July 2017) } \\
\text { It is getting worse because now } \\
\text { the sun is very high and hot and } \\
\text { so the disease is worse (Female } \\
\text { seaweed farmer partaking in } \\
\text { value addition, Paje, July 2019) }\end{array}$ \\
\hline $\begin{array}{l}\text { Increased } \\
\text { sea } \\
\text { temperatures }\end{array}$ & $\begin{array}{l}\text { Epiphytic algae, causes } \\
\text { seaweed to rot }\end{array}$ & $28 \%$ & $\begin{array}{l}\text { There is a type of seagrass that } \\
\text { grows on the seaweed and causes } \\
\text { it to rot... I wanted to cry } \\
\text { because there was so much } \\
\text { (Female farmer employed at the } \\
\text { seaweed business, Paje, July } \\
\text { 2019) }\end{array}$ \\
\hline $\begin{array}{l}\text { Increased } \\
\text { wind speed }\end{array}$ & $\begin{array}{l}\text { Lower yields as seaweed } \\
\text { breaks off the rope and } \\
\text { farms get destroyed }\end{array}$ & $50 \%$ & $\begin{array}{l}\text { Due to the changing of the } \\
\text { weather, the seaweed that we } \\
\text { plant gets ripped off by the wind. } \\
\text { We plant a lot but when we go to } \\
\text { harvest it there is not much there } \\
\text { (Independent female farmer, } \\
\text { Bweleo, July 2017) }\end{array}$ \\
\hline $\begin{array}{l}\text { Changes in } \\
\text { rainfall } \\
\text { patterns }\end{array}$ & $\begin{array}{l}\text { Lower yields as destroys the } \\
\text { harvest if it gets wet whilst } \\
\text { drying }\end{array}$ & $19 \%$ & $\begin{array}{l}\text { During the rainfall we plant it but } \\
\text { we don't harvest it because it is } \\
\text { difficult to dry it (Independent } \\
\text { female farmer, Paje, July 2017) }\end{array}$ \\
\hline
\end{tabular}

Deepwater farming is a group activity that uses a new technology to farm in the deeper and cooler water. It requires the involvement of men to drive a boat and swim to place nets, although some swimming lessons have been provided to some women. SeaPoWer farmers believed that seaweed grows better in deeper water, particularly the more valuable species cottonii and it was believed that the new method addresses environmental challenges. A comparison of the off-bottom method and the deepwater method reveals that disease and seagrass infestation were significantly less of a challenge for farmers using the deepwater technology compared to the off-bottom method (Table 4). However, the deepwater method elevated alternative challenges including the presence of grazers (fish-eating the seaweed) and the need for training (Table 4). Farmers have placed fish traps at the bottom of the tubular nets in the deepwater to capture the herbivorous fish to sell. Interviews reveal that there are constraints to adaptation methods (Table 3). For example, independent farmers expressed a desire to partake in value addition but noted that they lacked training and equipment. Similarly, to farm in the deeper water using the tubular technology, farmers need to learn to swim and dive, and have access to a boat. Currently, farmers have to rely on men because boat skills are highly gendered activities that are 


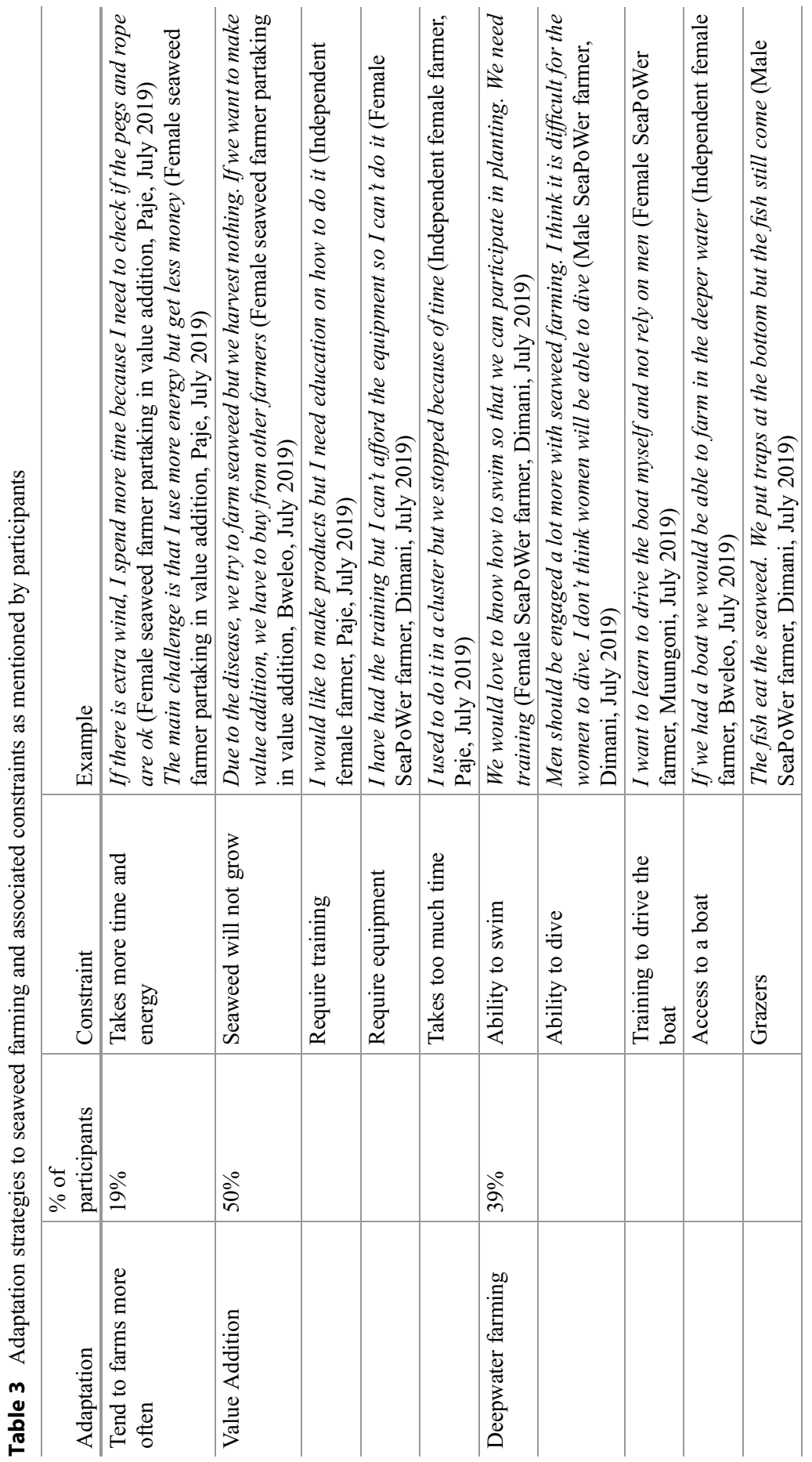


Table 4 Comparison of the challenges mentioned by participants for seaweed farming using the off-bottom method and deepwater farming. $\boldsymbol{P}$ value represents the significance levels from fisher's exact test. $*$ denotes significant results

\begin{tabular}{l|l|l|l}
\hline Challenge & Off-bottom method & Deepwater & $P$ value \\
\hline Disease & $64 \%$ & $20 \%$ & $p=0.028^{*}$ \\
\hline Epiphytes & $39 \%$ & $0 \%$ & $p=0.020^{*}$ \\
\hline Winds & $47 \%$ & $40 \%$ & $p>0.05$ \\
\hline Grazers & $6 \%$ & $50 \%$ & $p=0.0031^{*}$ \\
\hline Training & $0 \%$ & $60 \%$ & $p=0.0000022^{*}$ \\
\hline
\end{tabular}

associated with fishing activity. However, there is strong consensus among the female participants that women would like training to be able to do these activities themselves. These constraints highlight clear socioeconomic barriers to adaptation options.

\section{Discussion}

Seaweed farming, using the off-bottom method, is susceptible to shocks and stresses and climatic changes are clearly having a big impact on seaweed farmers. Initial benefits associated with seaweed farming, such as increased household income and job opportunities, become less obvious as harvests are increasingly unreliable which leads to greater insecurity. Many farmers observed increases in wind speed and temperature, which is in alignment with meteorological data and other studies (Hassan and Othman 2019; Makame and Shackleton 2019). The presence of "iceice" disease, which causes a discoloration of the seaweed thali and affects the quality of seaweed, is linked to changes in light intensity and temperature (Largo et al. 1995). The more valuable species (Cottonii) is particularly sensitive to environmental fluctuations, and seaweed die-offs caused by "ice-ice" disease is a widespread issue and has been long documented in Zanzibar (Msuya et al. 2014; Msuya and Porter 2014). Moreover, the invasion of epiphytic algae, which causes the seaweed to rot (Critchley et al. 2004; Vairappan 2006), has also been linked to increased variability in water temperatures (Tsiresy et al. 2016). The emotional response of farmers during the interviews to this problem clearly indicates the effect it has on income and human capital because of the economic insecurity and emotional response it causes. The difficulty of high die-off rates and therefore low yields is compounded by irregular rainfall patterns, which cause post-harvest loss of yields if it rains during the drying process, and a low-sale price. The combination of environmental and economic challenges results in a very low income for farmers and therefore threatens the economic capital of farmers by reducing their ability to generate a stable income. Seaweed farming is clearly susceptible to economic and environmental shocks and stresses. Given that future projections estimate that temperatures will increase by $1.5-2{ }^{\circ} \mathrm{C}$ by the 2050 s (Revolutionary Government of Zanzibar 2013), seaweed die-offs will be exacerbated and its sustainability is 
therefore questionable if adaptation is not achieved. Other challenges, such as poor health effects (Fröcklin et al. 2012), further impact sustainability by negatively affected human capital. The off-bottom method is negatively impacting human and economic capital and is becoming increasingly vulnerable to shocks and stresses. Therefore, it is important to understand indigenous perceptions about climate change and its impacts to assess the dynamic responses to changes and to determine suitable adaptation strategies to attain sustainable livelihoods.

There are a number of short-term and long-term adaptation strategies available to farmers. Intensification of farming (i.e., using "more energy" to tend to farms) is a short-term coping strategy in response to low production, high winds, and low sale price. Value addition is a form of long-term diversification, aiming to address the issue of a low sale price that farmers get as a result of their weak bargaining power with seaweed buyers. Interviews reveal that women clearly see the benefit of value addition through an increase in their income. Moreover, deepwater farming can be seen as either a form of extensification or a migration to a new production environment that successfully addresses many environmental challenges and farmers believe that they can earn more money by farming the more valuable species. Although there are still uncertainties regarding the outputs of these long-term adaptation strategies (value addition and deepwater farming), and further monitoring will be required to assess the impact that this has on the farmers' household income, the attitudes of farmers engaging with these activities are positive. The farming innovations are also bringing about additional benefits such as greater social capital by empowering women producers and elevating women's status in society (Brugere et al. 2020).

However, successful adaptation requires an enabling environment dependent on environmental, economic, social, and institutional factors and some strategies are more effective that others, particularly in relation to climate change. Although some longterm adaptation strategies are having positive impacts, there are a number of barriers to adaptation that warrant further attention, and adaptive strategies must be analyzed in the context of these barriers to assess their effectiveness. Given that climatic change is a major challenge for seaweed farmers that is likely to be exacerbated in the future, many adaptation strategies will not be adequate in ensuring the long-term sustainability of farming. For example, intensification of farming and value addition activities will not be resistant to climatic stressors because they do not address the inability to grow seaweed. Moreover, there are economic considerations that may inhibit farmers' ability to adapt; unlike the off-bottom method, deepwater farming and value addition both require large initial investment to purchase equipment. If farmers do not have the financial capacity to make this initial investment, adaptation will not be possible unless enabled through institutional or NGO support (Wright et al. 2014).

Social factors will also either inhibit or enable adaptation. Deepwater farming and value addition both require substantial training and knowledge sharing. Many independent farmers interviewed were aware of adaptation methods but were unable to access them, highlighting the importance of social collaboration as a critical enabling environment to promote knowledge sharing for adaptation ( $\mathrm{Fu}$ et al. 2011). Moreover, deeply engrained social practices and the complex nature of gender biases and power relations will be significant barriers to overcome for adaption methods. Labor-led intensification is characterized by an increased time burden, 
which disproportionately affects women due to their roles within the household and as child-carers (Wodon and Blackden 2006). Therefore, it is unlikely to be sustainable because of the impact on human and social capital by reducing time available for other roles that are typically dominated by women. The complex nature of gender biases and power relations also significantly affects deepwater farming, which currently entails the involvement of men. Gender power dynamics must be monitored to maintain (and promote) the positive impact to date of seaweed farming on women's security at the household and community level (Wallevik and Jiddawi 2001). Interviews revealed women want to learn to swim and drive the boat to reduce their dependency on men, highlighting a shift in traditional attitudes (Brugere et al. 2019; Brugere et al. 2020). Deepwater farming represents a shift in gender attitudes because it challenges the traditional belief that the deepwater is an area accessed by men due to women's limited mobility and role in society (Fröcklin et al. 2014). The government is promoting gender balance by increasing the number of female village leaders and females in government offices which shows a wider change in gendered roles. However, despite signs of attitude shifts, deeply engrained cultural practices and ways of thinking, held by both men and women, require repeated action, support, and perseverance over extensive periods of time to evolve (Brugere et al. 2019).

Lastly, government involvement will impact the success of adaptation methods by providing (or inhibiting) an institutional enabling environment. Policies and institutions play a major contributing role to the sustainability of coping and adaptation strategies (Osman-Elasha et al. 2006). Governance mechanisms aimed at adaptation can support coping strategies by providing training, technical support, and financial support (Jabeen et al. 2010). It is promising that there is government attention on seaweed farming in Zanzibar, highlighted by the recent appointment of National Seaweed Day to emphasize the importance of the activity and previous governmental attempts to increase the price of seaweed (Davis 2011). Moreover, there are currently plans to construct a processing plant on Pemba which is a large-scale value addition project (IPPmedia 2019). However, the government should be investing in technologies that will be resilient to climate change, not only promoting value addition activities which will be an ineffective coping strategy in the long-term.

Overall, short-term coping strategies are often ineffective and have resulted in many people ceasing to farm as seen by the reduction in farmer numbers in Bweleo and the reduction in production. Although long-term adaptation methods provide promising ways to increase the sustainability of seaweed farming by overcoming economic and environmental challenges, particularly those relating to climate change, there are significant socioeconomic barriers that need to be overcome. This will only be achieved through a supportive enabling environment with participation of local communities and institutional support (Sietz et al. 2011).

\section{Future Study}

Although 36 participants was deemed sufficient to enable thorough analysis due to the recurrence of themes during interviews, the study would benefit from incorporating the experiences of farmers on the other islands in Zanzibar, particularly Pemba 
where seaweed farming is a particularly important livelihood activity. More investigation is required into the potential cobenefit of using fish traps at deepwater farms to see if the catch of fish can outweigh the loss of seaweed yield. Moreover, there should be more research into drying techniques in order to reduce the post-harvest loss due to irregular rainfall, or the possibility of farmers selling seaweed fresh opposed to dried. Additionally, the complex issue of gender dynamics requires further study, particularly the possible shift in power as a result of extensification into deeper water, which could have major impacts on the long-term sustainability of seaweed farming as a way of empowering women.

\section{Wider Implications}

Seaweed farming is being promoted as an alternative livelihood activity in many tropical developing counties, including Zanzibar, Indonesia, and Philippines. However, it is important that alternative livelihood activities are resilient to ecological and social system fluctuations, particularly climate change (Allison and Ellis 2001). In order to maintain yields, efforts need to focus on seaweed farming adaptation strategies that will be resilient to climate change. Deepwater farming using the new tubular technology shows the most promising adaption method to environmental challenges. However, it requires significant investment and training to ensure its success. Interestingly, despite negative impacts of climate change on the growth of seaweed that have been reported in Zanzibar and elsewhere, seaweed aquaculture is gaining recognition as a climate-change mitigation strategy by its ability to act as a carbon sink (Duarte et al. 2017). Although it would be minor at this scale, it is worth exploring how climate change mitigation policies that provide economic compensation for the environmental benefits brought about by seaweed farming could help investment and could generate a new market for seaweed production (Duarte et al. 2017).

\section{Conclusion}

Seaweed farming is still heralded as a success story and is responsible for women's empowerment and economic liberation. However, climatic stressors such as increased sea temperatures, high winds, and variable rainfall reduce seaweed growth and quality. Given the current environmental and socio-economic challenges, seaweed farming provides an unreliable income. Despite the cultural importance as a livelihood activity, the future of seaweed farming is uncertain, particularly as the impacts around climate change are likely to increase. Individual short-term coping strategies, such as intensification of tending to seaweed farms are unlikely to be effective in the long-term. The sustainability of seaweed farming is reliant on longterm adaptation methods that will require adopting new technologies, overcoming significant socioeconomic barriers, and will demand substantial institutional support. It is important to support adaptation strategies that are codesigned with communities, and that use holistic approaches that embrace the technological, individual (social and economic), and institutional dimensions of climate change adaptation. 


\section{Supplementary Information}

\section{S1: List of Academics and NGOs Contacted During Scoping Phase}

\begin{tabular}{l|l}
\hline Name & Organisation \\
\hline Narriman Jiddawi & Department of Fisheries Development \\
\hline Flower Msuya & Zanzibar Seaweed Cluster Initiative \\
\hline Alice Mushi & Milele Foundation \\
\hline Cecile Brugere & SeaPoWer \\
\hline N/A & The Seaweed Company \\
\hline
\end{tabular}

\section{S2: Participant Profiles}

\begin{tabular}{|c|c|c|c|c|c|c|c|c|c|}
\hline & Participant & Group & Age & Gender & Village & Status & Children & Electricity & Water \\
\hline 1 & SWC1 & SWC & 48 & $\mathrm{~F}$ & Paje & Married & 3 & 1 & 1 \\
\hline 2 & SWC2 & SWC & 33 & $\mathrm{~F}$ & Jambiani & Divorced & 5 & 0 & 0 \\
\hline 3 & SWC3 & SWC & 66 & $\mathrm{~F}$ & Paje & Married & 8 & 0 & 1 \\
\hline 4 & SWC4 & SWC & 44 & $\mathrm{~F}$ & Paje & Married & 2 & 0 & 1 \\
\hline 5 & SWC5 & SWC & 25 & F & Paje & Divorced & 3 & 1 & 1 \\
\hline 6 & SWC6 & SWC & 23 & F & Paje & Married & 0 & 1 & 0 \\
\hline 7 & IND1 & IND & 34 & $\mathrm{~F}$ & Paje & Divorced & 4 & 1 & 1 \\
\hline 8 & IND2 & IND & 54 & $\mathrm{~F}$ & Paje & Married & 8 & 0 & 1 \\
\hline 9 & IND3 & IND & 70 & $\mathrm{~F}$ & Paje & Divorced & 1 & 0 & 1 \\
\hline 10 & IND6 & IND & 58 & $\mathrm{~F}$ & Paje & Divorced & 4 & 0 & 0 \\
\hline 11 & IND7 & IND & 57 & $\mathrm{~F}$ & Paje & Widowed & 3 & 0 & 0 \\
\hline 12 & IND8 & IND & 39 & $\mathrm{~F}$ & Paje & Widowed & 5 & 0 & 1 \\
\hline 13 & IND9 & IND & 32 & F & Paje & Married & 4 & 0 & 1 \\
\hline 14 & IND10 & IND & 42 & $\mathrm{~F}$ & Paje & Divorced & 3 & 1 & 1 \\
\hline 15 & IND & IND & 51 & $\mathrm{~F}$ & Bweleo & Widowed & 6 & 1 & 0 \\
\hline 16 & SP1 & SP & 64 & $\mathrm{~F}$ & Nyamanzi & Married & 5 & 1 & 0 \\
\hline 17 & SP2 & SP & 46 & $\mathrm{~F}$ & Dimani & Married & 6 & 0 & 1 \\
\hline 18 & SP3 & SP & 48 & $\mathrm{~F}$ & Dimani & Married & 12 & 0 & 0 \\
\hline 19 & SP4 & SP & 40 & $\mathrm{~F}$ & Nyamanzi & Married & 3 & 0 & 0 \\
\hline 20 & SP5 & SP & 41 & M & Dimani & Married & 3 & 0 & 0 \\
\hline 21 & SP6 & SP & 38 & $\mathrm{~F}$ & Muungoni & Married & 7 & 1 & 0 \\
\hline 22 & SP7 & SP & 52 & $\mathrm{~F}$ & Muungoni & Married & 5 & 1 & 0 \\
\hline 23 & SP8 & SP & 43 & $\mathrm{~F}$ & Muungoni & Married & 2 & 0 & 0 \\
\hline 24 & SP9 & SP & 52 & $\mathrm{~F}$ & Muungoni & Married & 7 & 1 & 0 \\
\hline 25 & SP10 & SP & 24 & $\mathrm{~F}$ & Muungoni & Married & 2 & 0 & 0 \\
\hline 26 & VA1 & VA & 40 & $\mathrm{~F}$ & Paje & Married & 4 & 1 & 1 \\
\hline 27 & VA2 & VA & 48 & $\mathrm{~F}$ & Paje & Married & 3 & 0 & 1 \\
\hline 28 & VA3 & VA & 46 & $\mathrm{~F}$ & Paje & Married & 2 & 1 & 1 \\
\hline 29 & VA4 & VA & 50 & F & Paje & Married & 4 & 1 & 1 \\
\hline
\end{tabular}




\begin{tabular}{l|l|l|l|l|l|l|l|l|l}
\hline & Participant & Group & Age & Gender & Village & Status & Children & Electricity & Water \\
\hline 30 & VA5 & VA & 42 & F & Paje & Married & 3 & 1 & 1 \\
\hline 31 & VA6 & VA & 54 & F & Bweleo & Married & 6 & 1 & 0 \\
\hline 32 & VA7 & VA & 25 & M & Bweleo & Single & 0 & 1 & 0 \\
\hline 33 & VA8 & VA & 45 & F & Bweleo & Married & 4 & 1 & 0 \\
\hline 34 & VA9 & VA & 56 & F & Bweleo & Married & 6 & 1 & 0 \\
\hline 35 & VA10 & VA & 40 & F & Paje & Married & 3 & 0 & 1 \\
\hline 36 & Va11 & VA & 50 & F & Paje & Married & 6 & 0 & 0 \\
\hline
\end{tabular}

\section{S3: Interview Questions Used as a Guideline for the Semi-structured Interviews}

\section{Registration:}

Age:

Gender:

Village/District:

Single/Married/Widowed:

Number of children:

Electricity in home:

Water piped in the home:

\section{Questions}

Background

How long have you been farming seaweed?

Why did you decide to start farming seaweed?

What do you think are the main benefits coming from seaweed farming?

What type of method do you use (shallow water/deepwater)?

- If you do both, why? If you changed from the traditional method to the new method, why?

- When did you start farming the new method?

What type of seaweed do you farm? Cotonii or Spinosum?

How much time do you spend farming seaweed in the traditional/deepwater method?

How many days a week do you spend farming?

\section{Economic}

Who do you sell the seaweed to?

How much money do you make from seaweed farming per month?

What is the price per unit ( $\mathrm{kg}$ bag of dried seaweed) Are you able to negotiate the prices?

Which method earns more money? Which species earns more money?

Has the value of the seaweed you farm increased, decreased or stayed the same in the last 20 years? 
How essential is seaweed farming to the income of the household?

Do you have any other sources of income other than seaweed farming?

What is the money from seaweed farming spent on?

Do you have a say on how the money from seaweed farming is spent?

What is the cost of the off bottom culture equipment per cycle of production?

If you have farmed using both methods, how do you think the deepwater technique compares with the traditional technique, in terms of

- Seaweed seedlings [more expensive, less expensive, the same]

- Equipment (ropes, pegs versus nets, strings, PVC tubes, boat, petrol. . .)

- Time/labour spent farming (more, less, the same)

\section{What challenges are you facing? (Off bottom method)}

Does the seaweed grow well?

Are these new/emerging challenges or have they always existed?

Are these challenges increasing/decreasing or staying the same?

Do the challenges vary across different seasons?

How do you respond to/cope with these challenges?

What would help to stop these problems?

Are you facing any health repercussions?

- Have these increased with exposure or stayed the same?

- How do you cope with or manage these health implications?

What does your family think of farming the new method/the old method?

- Does the time taken to farm seaweed affect your family?

Has there been any spatial conflict with other users of the ocean space? - eg does tourism or fisherman prevent you from farming?

- How do you manage this?

Is there anything that would make it easier for you?

Do you farm in the deepwater?

How much time do you spend on this?

What effect does this have on your income?

What are the challenges?

Do you do any value addition - making products?

How much time do you spend on making products? What equipment and/or inputs are you using?

How/where do you sell your products?

What products do you make?

Is there anything else that you would like to add or say? 


\section{S4: Coding Strategy Used to Analyses the Seaweed Farming Interview Data}

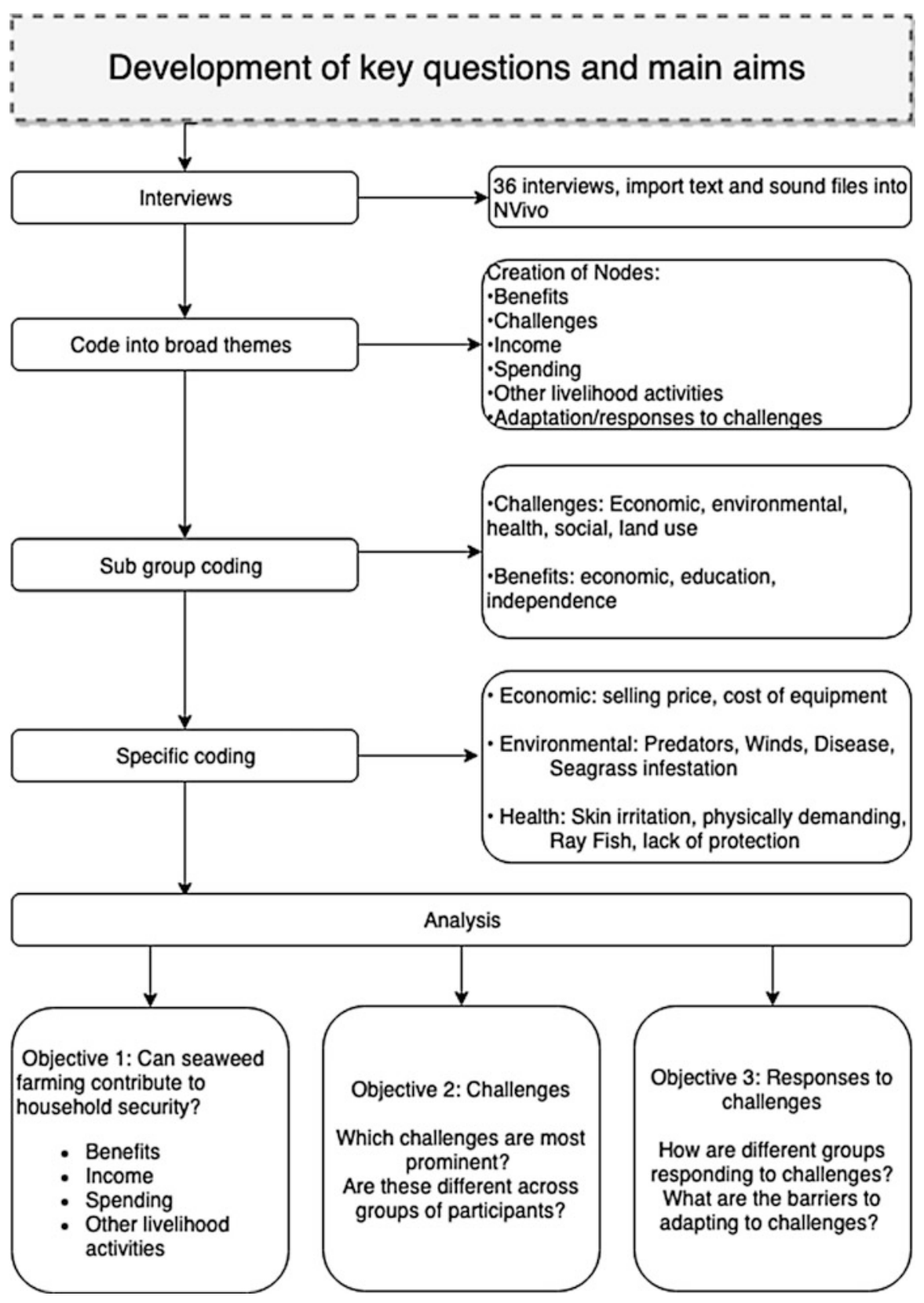




\section{S5: Presen6ce Absence Data for Challenges to the Off Bottom Method}

\begin{tabular}{|c|c|c|c|c|c|c|c|c|c|c|c|c|}
\hline \begin{tabular}{l}
$\stackrel{0}{0}$ \\
\multirow{3}{0}{}
\end{tabular} & $\begin{array}{l}\vec{D} \\
\bar{E} \\
\text { एँ }\end{array}$ & $\stackrel{\mathscr{0}}{D}$ & 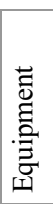 & 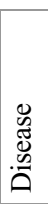 & 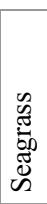 & 离 & $\stackrel{\mathscr{0}}{\Xi}$ & 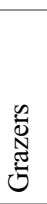 & 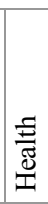 & 兽 & 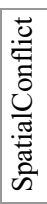 & 青 \\
\hline SWC & Off_Bottom & 0 & 0 & 1 & 0 & 1 & 0 & 0 & 1 & 0 & 0 & 0 \\
\hline SWC & Off_Bottom & 1 & 0 & 1 & 1 & 0 & 0 & 0 & 0 & 0 & 0 & 0 \\
\hline SWC & Off_Bottom & 1 & 0 & 0 & 1 & 0 & 0 & 0 & 1 & 0 & 0 & 0 \\
\hline SWC & Off_Bottom & 1 & 0 & 1 & 0 & 1 & 1 & 0 & 0 & 0 & 0 & 0 \\
\hline SWC & Off_Bottom & 0 & 0 & 0 & 0 & 0 & 1 & 0 & 0 & 0 & 1 & 0 \\
\hline SWC & Off_Bottom & 0 & 0 & 0 & 1 & 0 & 1 & 0 & 0 & 0 & 0 & 1 \\
\hline IND & Off_Bottom & 1 & 1 & 0 & 1 & 1 & 1 & 0 & 1 & 0 & 1 & 1 \\
\hline IND & Off_Bottom & 1 & 0 & 1 & 0 & 1 & 1 & 0 & 1 & 0 & 0 & 1 \\
\hline IND & Off_Bottom & 1 & 1 & 0 & 1 & 0 & 1 & 0 & 0 & 0 & 0 & 0 \\
\hline IND & Off_Bottom & 1 & 0 & 0 & 0 & 1 & 1 & 1 & 1 & 0 & 1 & 1 \\
\hline IND & Off_Bottom & 1 & 0 & 1 & 0 & 0 & 1 & 0 & 1 & 0 & 1 & 0 \\
\hline IND & Off_Bottom & 1 & 1 & 1 & 0 & 1 & 0 & 0 & 0 & 0 & 1 & 0 \\
\hline IND & Off_Bottom & 1 & 0 & 0 & 0 & 0 & 0 & 0 & 0 & 0 & 1 & 1 \\
\hline IND & Off_Bottom & 1 & 1 & 1 & 0 & 0 & 0 & 0 & 1 & 0 & 0 & 1 \\
\hline IND & Off_Bottom & 0 & 0 & 0 & 1 & 0 & 1 & 1 & 0 & 0 & 0 & 0 \\
\hline SP & Off_Bottom & 1 & 1 & 1 & 1 & 1 & 1 & 0 & 0 & 0 & 0 & 0 \\
\hline SP & Off_Bottom & 1 & 1 & 1 & 1 & 1 & 0 & 0 & 1 & 0 & 0 & 0 \\
\hline SP & Off_Bottom & 1 & 1 & 0 & 1 & 0 & 1 & 0 & 1 & 0 & 1 & 0 \\
\hline SP & Off_Bottom & 0 & 1 & 1 & 1 & 1 & 0 & 0 & 1 & 0 & 0 & 0 \\
\hline SP & Off_Bottom & 0 & 0 & 1 & 0 & 1 & 1 & 0 & 1 & 0 & 0 & 1 \\
\hline SP & Off_Bottom & 1 & 1 & 1 & 0 & 1 & 0 & 0 & 0 & 0 & 1 & 1 \\
\hline SP & Off_Bottom & 0 & 1 & 1 & 0 & 0 & 0 & 0 & 0 & 0 & 1 & 0 \\
\hline SP & Off_Bottom & 0 & 1 & 1 & 0 & 0 & 0 & 0 & 1 & 0 & 1 & 0 \\
\hline SP & Off_Bottom & 0 & 1 & 1 & 0 & 1 & 0 & 0 & 0 & 0 & 0 & 0 \\
\hline SP & Off_Bottom & 0 & 0 & 1 & 0 & 1 & 1 & 0 & 0 & 0 & 1 & 0 \\
\hline VA & Off_Bottom & 1 & 0 & 1 & 0 & 1 & 0 & 0 & 1 & 0 & 1 & 0 \\
\hline VA & Off_Bottom & 1 & 0 & 0 & 1 & 0 & 1 & 0 & 1 & 0 & 0 & 0 \\
\hline VA & Off_Bottom & 0 & 0 & 0 & 0 & 1 & 1 & 0 & 0 & 0 & 1 & 1 \\
\hline VA & Off_Bottom & 1 & 0 & 1 & 0 & 1 & 0 & 0 & 0 & 0 & 1 & 0 \\
\hline VA & Off_Bottom & 1 & 1 & 1 & 0 & 1 & 0 & 0 & 1 & 0 & 0 & 0 \\
\hline VA & Off_Bottom & 0 & 1 & 1 & 0 & 0 & 0 & 0 & 0 & 0 & 0 & 0 \\
\hline VA & Off_Bottom & 1 & 0 & 0 & 1 & 0 & 0 & 0 & 1 & 0 & 1 & 0 \\
\hline VA & Off_Bottom & 0 & 0 & 0 & 1 & 0 & 0 & 0 & 1 & 0 & 0 & 0 \\
\hline VA & Off_Bottom & 1 & 1 & 1 & 0 & 0 & 0 & 0 & 0 & 0 & 0 & 0 \\
\hline VA & Off_Bottom & 0 & 1 & 1 & 1 & 1 & 1 & 0 & 1 & 0 & 1 & 0 \\
\hline VA & Off_Bottom & 0 & 1 & 1 & 0 & 1 & 1 & 0 & 1 & 0 & 1 & 1 \\
\hline
\end{tabular}




\section{S6: Presence Absence of Challenges for Deepwater and off Bottom} Methods

\begin{tabular}{|c|c|c|c|c|c|c|c|c|c|c|}
\hline $\begin{array}{l}\stackrel{0}{0} \\
\stackrel{0}{0}\end{array}$ & 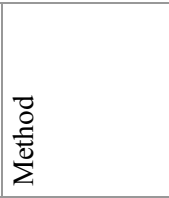 & 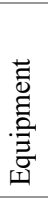 & 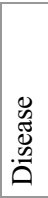 & 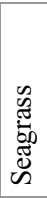 & 节 & $\frac{n}{3}$ & 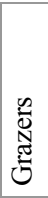 & 恶 & 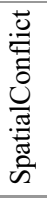 & 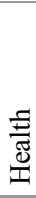 \\
\hline SWC & Off_Bottom & 0 & 1 & 0 & 1 & 0 & 0 & 0 & 0 & 0 \\
\hline SWC & Off_Bottom & 0 & 1 & 1 & 0 & 0 & 0 & 0 & 0 & 0 \\
\hline SWC & Off_Bottom & 0 & 0 & 1 & 0 & 0 & 0 & 0 & 0 & 1 \\
\hline SWC & Off_Bottom & 0 & 1 & 0 & 1 & 1 & 0 & 0 & 0 & 0 \\
\hline SWC & Off_Bottom & 0 & 0 & 0 & 0 & 1 & 0 & 0 & 1 & 0 \\
\hline SWC & Off_Bottom & 0 & 0 & 1 & 0 & 1 & 0 & 0 & 0 & 0 \\
\hline IND & Off_Bottom & 1 & 0 & 1 & 1 & 1 & 0 & 0 & 1 & 1 \\
\hline IND & Off_Bottom & 0 & 1 & 0 & 1 & 1 & 0 & 0 & 0 & 1 \\
\hline IND & Off_Bottom & 1 & 0 & 1 & 0 & 1 & 0 & 0 & 0 & 0 \\
\hline IND & Off_Bottom & 0 & 0 & 0 & 1 & 1 & 1 & 0 & 1 & 1 \\
\hline IND & Off_Bottom & 0 & 1 & 0 & 0 & 1 & 0 & 0 & 1 & 1 \\
\hline IND & Off_Bottom & 1 & 1 & 0 & 1 & 0 & 0 & 0 & 1 & 0 \\
\hline IND & Off_Bottom & 0 & 0 & 0 & 0 & 0 & 0 & 0 & 1 & 0 \\
\hline IND & Off_Bottom & 1 & 1 & 0 & 0 & 0 & 0 & 0 & 0 & 1 \\
\hline IND & Off_Bottom & 0 & 0 & 1 & 0 & 1 & 1 & 0 & 0 & 0 \\
\hline SP & Off_Bottom & 1 & 1 & 1 & 1 & 1 & 0 & 0 & 0 & 0 \\
\hline SP & Off_Bottom & 1 & 1 & 1 & 1 & 0 & 0 & 0 & 0 & 1 \\
\hline SP & Off_Bottom & 1 & 0 & 1 & 0 & 1 & 0 & 0 & 1 & 1 \\
\hline SP & Off_Bottom & 1 & 1 & 1 & 1 & 0 & 0 & 0 & 0 & 1 \\
\hline SP & Off_Bottom & 0 & 1 & 0 & 1 & 1 & 0 & 0 & 0 & 1 \\
\hline SP & Off_Bottom & 1 & 1 & 0 & 1 & 0 & 0 & 0 & 1 & 0 \\
\hline SP & Off_Bottom & 1 & 1 & 0 & 0 & 0 & 0 & 0 & 1 & 0 \\
\hline SP & Off_Bottom & 1 & 1 & 0 & 0 & 0 & 0 & 0 & 1 & 1 \\
\hline SP & Off_Bottom & 1 & 1 & 0 & 1 & 0 & 0 & 0 & 0 & 0 \\
\hline SP & Off_Bottom & 0 & 1 & 0 & 1 & 1 & 0 & 0 & 1 & 0 \\
\hline VA & Off_Bottom & 0 & 1 & 0 & 1 & 0 & 0 & 0 & 1 & 1 \\
\hline VA & Off_Bottom & 0 & 0 & 1 & 0 & 1 & 0 & 0 & 0 & 1 \\
\hline VA & Off_Bottom & 0 & 0 & 0 & 1 & 1 & 0 & 0 & 1 & 0 \\
\hline VA & Off_Bottom & 0 & 1 & 0 & 1 & 0 & 0 & 0 & 1 & 0 \\
\hline VA & Off_Bottom & 1 & 1 & 0 & 1 & 0 & 0 & 0 & 0 & 1 \\
\hline VA & Off_Bottom & 1 & 1 & 0 & 0 & 0 & 0 & 0 & 0 & 0 \\
\hline VA & Off_Bottom & 0 & 0 & 1 & 0 & 0 & 0 & 0 & 1 & 1 \\
\hline VA & Off_Bottom & 0 & 0 & 1 & 0 & 0 & 0 & 0 & 0 & 1 \\
\hline VA & Off_Bottom & 1 & 1 & 0 & 0 & 0 & 0 & 0 & 0 & 0 \\
\hline VA & Off_Bottom & 1 & 1 & 1 & 1 & 1 & 0 & 0 & 1 & 1 \\
\hline VA & Off_Bottom & 1 & 1 & 0 & 1 & 1 & 0 & 0 & 1 & 1 \\
\hline SP & Deep_Water & 0 & 0 & 0 & 0 & 0 & 1 & 0 & 0 & 0 \\
\hline
\end{tabular}




\begin{tabular}{|c|c|c|c|c|c|c|c|c|c|c|}
\hline 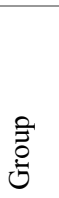 & 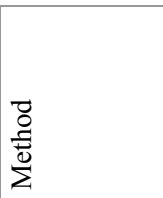 & 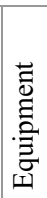 & 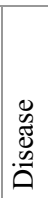 & 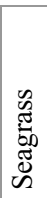 & 节 & $\frac{n}{3}$ & 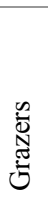 & 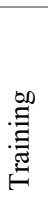 & 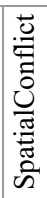 & 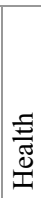 \\
\hline SP & Deep_Water & 0 & 0 & 0 & 0 & 1 & 0 & 1 & 0 & 0 \\
\hline SP & Deep_Water & 0 & 0 & 0 & 0 & 0 & 0 & 1 & 0 & 0 \\
\hline SP & Deep_Water & 0 & 0 & 0 & 0 & 0 & 1 & 0 & 0 & 0 \\
\hline SP & Deep_Water & 0 & 0 & 0 & 0 & 1 & 1 & 1 & 0 & 1 \\
\hline SP & Deep_Water & 1 & 0 & 0 & 0 & 0 & 1 & 1 & 1 & 0 \\
\hline SP & Deep_Water & 0 & 1 & 0 & 0 & 1 & 0 & 1 & 0 & 0 \\
\hline SP & Deep_Water & 0 & 0 & 0 & 0 & 1 & 0 & 0 & 1 & 1 \\
\hline SP & Deep_Water & 1 & 1 & 0 & 0 & 0 & 1 & 0 & 0 & 0 \\
\hline SP & Deep_Water & 0 & 0 & 0 & 0 & 0 & 0 & 1 & 0 & 0 \\
\hline
\end{tabular}

\section{S7: Percentage of Participants Spending Their Income from Seaweed Farming on Various Items}

\begin{tabular}{l|l}
\hline Item & $\%$ Participants \\
\hline School fees & $69.4 \%$ \\
\hline Food & $55.5 \%$ \\
\hline Everyday household expenses & $38.9 \%$ \\
\hline Clothes & $36.1 \%$ \\
\hline Savings & $30.5 \%$ \\
\hline Personal use & $27.8 \%$ \\
\hline House renovations & $25.0 \%$ \\
\hline Extra household commodities & $19.4 \%$ \\
\hline
\end{tabular}

\section{References}

Adger WN, Arnell NW, Tompkins EL (2005) Successful adaptation to climate change across scales. Glob Environ Change 15(2):77-86

Allison EH, Ellis F (2001) The livelihoods approach and management of small-scale fisheries. Mar Policy 25(5):377-388

Arnold S (2008) Seaweed, power, and markets: a political ecology of the Caluya Islands, Philippines (Major paper). York University, Toronto

Brown K, Westaway E (2011) Agency, capacity, and resilience to environmental change: lessons from human development, well-being, and disasters. Annu Rev Environ Resour 36:321-342

Brugere C, Msuya FE, Jiddawi N, Nyonje B, Maly R (2019) The introduction of an improved seaweed farming technology for women's empowerment, livelihoods and environmental protection. Institute of Marine Sciences, Zanzibar. https://doi.org/10.13140/RG.2.2.34671.69280 
Brugere C, Msuya FE, Jiddawi N, Nyonje B, Maly R (2020) Can innovation empower? Reflections on introducing tubular nets to women seaweed farmers in Zanzibar. Gender, Technology and Development, pp 1-21

Bryceson I (2002) Coastal aquaculture developments in Tanzania. Sustainable and non-sustainable experiences. West Indian Ocean J Mar Sci 1:1-10

Cohen PJ, Lawless S, Dyer M, Morgan M, Saeni E, Teioli H, Kantor P (2016) Understanding adaptive capacity and capacity to innovate in social-ecological systems: applying a gender lens. Ambio 45(3):309-321

Crawford B (2002) Seaweed farming: an alternative livelihood for small-scale fishers. Coastal Resources Center, Narragansett

Critchley AT, Largo D, Wee W, Bleicher L'honneur G, Hurtado AQ, Schubert J (2004) A preliminary summary on Kappaphycus farming and the impact of epiphytes. Japanese J Phycol 52(Supplement):231-232

Davis E (2011) Seaweed farmer education: is it enough to sustain the industry? Analyzing the status of stakeholder investment in Muungoni and Jambiani, Unguja. Independent Study Project (ISP) Collection. 1195. https://digitalcollections.sit.edu/isp_collection/1195

Department of Fisheries Development (2019) Export of Seaweed for the period 2008-2018. Ministry of Agriculture, Natural Resources, Livestock and Fisheries

Duarte CM, Wu J, Xiao X, Bruhn A, Krause-Jensen D (2017) Can seaweed farming play a role in climate change mitigation and adaptation? Front Mar Sci 4:100

Eklöf JS, de la Torre Castro M, Adelsköld L, Jiddawi NS, Kautsky N (2005) Differences in macrofaunal and seagrass assemblages in seagrass beds with and without seaweed farms. Estuar Coast Shelf Sci 63(3):385-396

Eklöf JS, Msuya FE, Lyimo TJ, Buriyo AS (2012) Seaweed farming in Chwaka Bay: a sustainable alternative in aquaculture. People, nature and research in Chwaka Bay. WIOMSA, Zanzibar, pp 213-233

Ferrol-Schulte D et al (2015) Coastal livelihood vulnerability to marine resource degradation: a review of the Indonesian national coastal and marine policy framework. Mar Policy. Pergamon 52:163-171

Fröcklin S et al (2012) Seaweed mariculture as a development project in Zanzibar, East Africa: a price too high to pay? Aquaculture Elsevier 356-357:30-39

Fröcklin S, de la Torre-Castro M, Håkansson E, Carlsson A, Magnusson M, Jiddawi NS (2014) Towards improved management of tropical invertebrate fisheries: including time series and gender. PLoS One 9(3):e91161

Hassan IH, Othman WJ (2019) Seaweed (Mwani) farming as an adaptation strategy to impacts of climate change and variability in Zanzibar. In: Climate change and coastal resources in Tanzania. Springer, Cham, pp 53-68

IPPmedia (2019) Zanzibar in final stages to construct a giant seaweed processing plant. https://ippmedia.com/en/business/zanzibar-final-stages-construct-giant-seaweed-processingplant. Accessed 8 Sept 2019

Jabeen H, Johnson C, Allen A (2010) Built-in resilience: learning from grassroots coping strategies for climate variability. Environ Urban 22(2):415-431

Largo DB, Fukami K, Nishijima T (1995) Occasional pathogenic bacteria promoting ice-ice disease in the carrageenan-producing red algae Kappaphycus alvarezii and Eucheuma denticulatum (Solieriaceae, Gigartinales, Rhodophyta). J Appl Phycol 7(6):545-554

Mahongo SB, Francis J (2010) Monthly variations in sea level at the island of Zanzibar. Western Indian Ocean J Mar Sci 9(1):1-16

Makame MO, Shackleton S (2019) Perceptions of climate variability and change in relation to observed data among two east coast communities in Zanzibar, East Africa. Clim Dev:1-13

Msuya FE (2006a) The impact of seaweed farming on the social and economic structure of seaweed farming communities in Zanzibar, Tanzania. World Seaweed Resources, Version, 1, p 27 
Msuya FE (2006b, September) The seaweed cluster initiative in Zanzibar, Tanzania. In: Proceedings of the 3rd regional conference on innovation systems and innovative clusters in Africa, Dar es Salaam, Tanzania, pp 246-260

Msuya FE (2011) The impact of seaweed farming on the socioeconomic status of coastal communities in Zanzibar, Tanzania. World Aquacult 42(3):45-48

Msuya FE, Porter M (2014) Impact of environmental changes on farmed seaweed and farmers: the case of Songo Songo Island, Tanzania. J Appl Phycol 26(5):2135-2141

Msuya FE, Shalli MS, Sullivan K, Crawford B, Tobey J, Mmochi AJ (2007) A comparative economic analysis of two seaweed farming methods in Tanzania. The Sustainable Coastal Communities and Ecosystems Program. Coastal Resources Center, University of Rhode Island and the Western Indian Ocean Marine Science Association.

Msuya FE, Buriyo A, Omar I, Pascal B, Narrain K, Ravina JJ, Mrabu E, Wakibia JG (2014) Cultivation and utilisation of red seaweeds in the Western Indian Ocean (WIO) region. J Appl Phycol 26(2):699-705

Namudu MT, Pickering TD (2006) Rapid survey technique using socio-economic indicators to assess the suitability of Pacific Island rural communities for Kappaphycus seaweed farming development. In: Eighteenth international seaweed symposium. Springer, Dordrecht, pp 15-23

Newman RJS, Capitani C, Courtney-Mustaphi C, Thorn JPR, Kariuki R, Enns C, Marchant R (2020) Integrating insights from social-ecological interactions into sustainable land use change scenarios for Small Islands in the Western Indian Ocean. Sustainability 12(4):1340

Osman-Elasha B, Goutbi N, Spanger-Siegfried E, Dougherty B, Hanafi A, Zakieldeen S, Sanjak A, Atti HA, Elhassan HM (2006) Adaptation strategies to increase human resilience against climate variability and change: lessons from the arid regions of Sudan. Assessments of impacts and adaptations to climate change (AIACC) working paper, 42

Quandt A (2018) Measuring livelihood resilience: the household livelihood resilience approach (HLRA). World Dev 107:253-263

Revolutionary Government of Zanzibar (2013) Zanzibar climate change strategy. http://www. paulwatkiss.co.uk/newimagesanddocs/ZanzibarSummaryLRdraftfinal.pdf. Accessed 2 Sept 2019

Salafsky N, Wollenberg E (2000) Linking livelihoods and conservation: a conceptual framework and scale for assessing the integration of human needs and biodiversity. World Dev 28(8):14211438

Sandelowski M (1995) Sample size in qualitative research. Res Nurs Health 18(2):179-183

Scoones I (1998) Sustainable rural livelihoods: a framework for analysis. IDS working paper no. 72, Institute of Development Studies, Brighton

Serrat O (2017) The sustainable livelihoods approach. In: Knowledge solutions. Springer Singapore, Singapore, pp 21-26

Sietz D, Boschutzz M, Klein RJT (2011) Mainstreaming climate adaptation into development assistance: rationale, institutional barriers and opportunities in Mozambique. Environ Sci Policy 14(4):493-502

Sievanen L, Crawford B, Pollnac R, Lowe C (2005) Weeding through assumptions of livelihood approaches in ICM: seaweed farming in the Philippines and Indonesia. Ocean Coast Manag 48 (3-6):297-313

Spencer L, Ritchie J, O'Connor W (2003) Analysis: practices, principles and processes. Qualitative research practice: a guide for social science students and researchers, SAGE, London, 199, p 218

Suckall N, Tompkins E, Stringer L (2014) Identifying trade-offs between adaptation, mitigation and development in community responses to climate and socio-economic stresses: Evidence from Zanzibar, Tanzania. Appl Geogr Pergamon 46:111-121

Temple B, Young A (2004) Qualitative research and translation dilemmas. Qual Res 4(2):161-178

Tobisson E (2014) Consequences and challenges of tourism and seaweed farming: a narrative on a coastal community in Zanzibar. Western Indian Ocean J Mar Sci 12(2):169-184 
Tsiresy G, Preux J, Lavitra T, Dubois P, Lepoint G, Eeckhaut I (2016) Phenology of farmed seaweed Kappaphycus alvarezii infestation by the parasitic epiphyte Polysiphonia sp. in Madagascar. J Appl Phycol 28(5):2903-2914

Vairappan CS (2006) Seasonal occurrences of epiphytic algae on the commercially cultivated red alga Kappaphycus alvarezii. J Appl Phycol 18(3-5):611-617

Valderrama D et al (2015) The economics of Kappaphycus seaweed cultivation in developing countries: a comparative analysis of farming systems. Aquac Econ Manag 19(2):251-277

Wallevik HB, Jiddawi N (2001) Impacts of tourism on the activities of the women of the southeast coast of Unguja, Zanzibar. In Marine Science Development in Tanzania and Eastern Africa. Proceedings of the 20 th Anniversary Conference on Advances in Marine Science in Tanzania 28:535-550

Wodon Q, Blackden CM eds., (2006) Gender, time use, and poverty in sub-Saharan Africa. The World Bank

Wright H, Vermeulen S, Laganda G, Olupot M, Ampaire E, Jat ML (2014) Farmers, food and climate change: ensuring community-based adaptation is mainstreamed into agricultural programmes. Clim Dev 6(4):318-328

ZaSCi (2019) Zanzibar Seaweed cluster initiative. https://www.mzfn.org/Advocacy_For_Seaweed. html. Date accessed 2/09/19

Open Access This chapter is licensed under the terms of the Creative Commons Attribution 4.0 International License (http://creativecommons.org/licenses/by/4.0/), which permits use, sharing, adaptation, distribution and reproduction in any medium or format, as long as you give appropriate credit to the original author(s) and the source, provide a link to the Creative Commons license and indicate if changes were made.

The images or other third party material in this chapter are included in the chapter's Creative Commons license, unless indicated otherwise in a credit line to the material. If material is not included in the chapter's Creative Commons license and your intended use is not permitted by statutory regulation or exceeds the permitted use, you will need to obtain permission directly from the copyright holder.

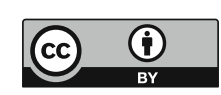

